\title{
From the Associate Editor
}

\author{
Barbara Sawhill \\ Oberlin College
}

I considered it a great honor when Andrew Ross asked me to be a part of the editorialstaff of the LALLTjournal. Ithas been a delightful, creative, thoughtful (albeit somewhat time-consuming) process to bring this issue to you. Bringing an edition of the journal to print provides all of us with yet another way of sharing our areas of expertise with one another as professionals. It also serves to make visible to other colleagues the types of research and investigation that we do as language technology professionals. The articles contained here affirm that there is an international community of people who do what we do and understand why and how we do it.

When meeting with colleagues from around the country at regional IALLT meetings, I am struck that many of us face a type of identity crisis in our home work environments. Generally, each of us hold a job on our campus that is unique: the skill sets that we are expected to bring to the table each day in order to accomplish our goals are often unlike any other job on campus. This difference can lead to misunderstanding members of the academic communityoutside of our domain often have a vague idea about what we do. Too often not knowing what we accomplish can lead colleagues to make assumptions about our work that has little basis in reality... leading to a potentially unhealthy series of dynamics when budget cuts and performance evaluations come to pass.

In our current economic climate, language technology professionals must become more visible. Their wealth of skills and knowledge need to be better understood and appreciated primarily because language technologists have extraordinary experience and expertise in the area of teaching and learning with technology that can extend beyond the boundaries of language learning: itis becomingincreasingly evident that what we know and what we teach to others has become more and more interesting to other disciplines as well. Still, our primary objective needs to be the support emphasis of the importance weaving technology into the pedagogy of language leaming. 
The IALLTJoumal serves as a way notonly to bring credibility to what all of us do as professionals at our respective places of work, but continues the dialogue about the accomplishments made by people of our profession. This is crucial to our professional growth and development. The IALLT Journal seeks to not only represent our colleagues' hard and thoughtful work, but it also provides status and legitimacy to the unique work we do.

We welcome the opportunity to read more submissions from the IALLT community about what you may have investigated, researched, developed or created to provide the language learning community with pedagogicallysound language learning technology.

See you in Ann Arbor at IALLT 2003! • 